\title{
THE EFFECT OF ADDING INTRATHECAL MAGNESIUM SULPHATE TO BUPIVACAINE-FENTANYL SPINAL ANAESTHESIA
}

\author{
Bala Subramani Murugesan'1, Chithra Devi Ramakrishnan²
}

${ }^{1}$ Assistant Professor, Department of Anaesthesiology, Government Theni Medical College, Theni.

${ }^{2}$ Assistant Professor, Department of Anaesthesiology, Government Theni Medical College, Theni.

\section{ABSTRACT}

\section{BACKGROUND}

Spinal anaesthesia plays an important role of alleviating pain intraoperatively, extending into post-operative period also. Many drugs have been tried in search for an ideal adjuvant like opioids, soda bicarbonate, ketamine, neostigmine and midazolam. The magnesium sulphate with different mode of action prolong the Bupivacaine-Fentanyl spinal anaesthesia.

\section{MATERIALS AND METHODS}

The study was conducted in 70 patients undergoing elective lower extremity surgeries. After routine preoperative assessment as for all elective surgery patients, they were premedicated and patients were randomly allocated into two groups. Group S received Inj. 0.5\% Bupivacaine $2 \mathrm{cc}+$ Inj. Fentanyl $0.5 \mathrm{cc}+0.9 \% \mathrm{NaCl}$ solution $1 \mathrm{cc}$, Group M received Inj. 0.5\% Bupivacaine $2 \mathrm{cc}+$ Inj. Fentanyl 0.5 $\mathrm{cc}+50 \mathrm{mg}$ of 5\% MgSO4 $1 \mathrm{cc}$. On preoperative visit, the patients were explained about the procedure details. Patients were put on sitting position and with strict aseptic precaution lumbar puncture was done. The assigned amount of drug is premixed in a sterile syringe was injected as per the group assigned. After injection patient were put up in supine position. After attaining adequate peak level of sensory block, the surgeon was asked to proceed. If needed oxygen was given through ventimask. The results were observed.

\section{RESULTS}

The main finding of this study is that in patients undergoing lower extremity surgery under bupivacaine-fentanyl spinal anaesthesia, the addition of $50 \mathrm{mg}$ IT MgSO4 led to a significant delay in the onset of both sensory and motor blockade and prolonged the duration of spinal anaesthesia without increasing side effects. The mean duration of spinal anaesthesia was significantly prolonged by magnesium to $209 \mathrm{mts}$. No case had respiratory depression intraoperatively as well as in post-operative period in this study. In this study, the respiratory rate remained unchanged with the baseline and the haemodynamics were stable in the magnesium group.

\section{CONCLUSION}

From this study it was concluded that in patients undergoing lower extremity surgery, IT MgSO4 (50 mg), when added to spinal anaesthesia induced by bupivacaine and fentanyl, delayed the onset of both sensory and motor blockade and prolonged the duration of anaesthesia without increasing the incidence of side effects.

\section{KEYWORDS}

Spinal Anaesthesia, Intrathecal, Post-Operative.

HOW TO CITE THIS ARTICLE: Murugesan BS, Ramakrishnan CD. The effect of adding intrathecal magnesium sulphate to bupivacaine-fentanyl spinal anaesthesia. J. Evolution Med. Dent. Sci. 2016;5(98):7185-7191, DOI: 10.14260/jemds/2016/1626

\section{BACKGROUND}

Spinal anaesthesia plays an important role of alleviating pain intraoperatively, extending into post-operative period also. A pain free post-operative period is necessary for both physical and psychological wellbeing of the patient.

The first neuraxial block performed by J. Leonard Corning by injecting cocaine paved the way for the greatest leap into spinal anaesthesia. He coined the term "Spinal Anaesthesia."

First planned spinal analgesia for surgery in man performed by August Bier on 16 th August 1898, in Kiel when he injected $3 \mathrm{~mL}$ of $0.5 \%$ cocaine solution into a 34 -year-old labourer.

Financial or Other, Competing Interest: None.

Submission 19-11-2016, Peer Review 01-12-2016,

Acceptance 03-12-2016, Published 08-12-2016.

Corresponding Author:

Dr. Bala Subramani Murugesan,

\#H17/420, Doctors Avenue,

Chatrapatti Road,

Mullai Nagar, Aranmanai Pudur (P.O),

Theni-625531, Tamilnadu.

E-mail: balsanaes@rediffmail.com

DOI: $10.14260 /$ jemds/2016/1626
This was followed by successful and enthusiastic practice of spinal anaesthesia by "Rudolph Matas" in New Orleans and "Theodore Tuffier" in France. For lower extremity surgeries, the standard and most frequently employed anaesthetic technique is subarachnoid block. It provides superior analgesia and reduces perioperative complications compared with general anaesthesia.

The first spinal adjuvant adrenaline increase the duration and reduce the toxicity of spinal anaesthesia. From then many drugs have been tried in search for an ideal adjuvant. Like opioids, soda bicarbonate, ketamine, neostigmine and midazolam. The magnesium sulphate with different mode of action prolong the Bupivacaine-Fentanyl spinal anaesthesia. ${ }^{1,2,3,4}$

The demonstration of the opiate receptor in the substantia gelatinosa of the spinal cord (Yaksh and Rudy - 1976) has created interest in the intrathecal administration of opiates. ${ }^{5}$

Opioids are commonly added adjuvant to local anaesthetics in spinal anaesthesia. However, significant adverse effects such as pruritus, urinary retention, respiratory depression, haemodynamic instability and occasionally severe nausea and vomiting may limit their use. Adding magnesium 
may also improve the quality and increase the duration of spinal anaesthesia.

Magnesium blocks the N-methyl-D-aspartate (NMDA) channels in a voltage dependent way, producing a dramatic reduction in NMDA induced currents. In experimental studies, Intrathecal (IT) administration of magnesium sulphate (MgSO4) significantly potentiated opioids ant nociception in rats during spinal anaesthesia in acute incisional model. ${ }^{6}$

Magnesium has been used safely intrathecally in humans, and its safety profile has been documented by histopathological analysis in experimental studies. ${ }^{7,8}$

Hence, the present study has been undertaken to test the hypothesis that in patients undergoing lower extremity surgeries under Bupivacaine-Fentanyl spinal anaesthesia, the duration of anaesthesia would be prolonged by intrathecal $\mathrm{MgSO}_{4}$ (50 mg).

Regional anaesthesia is the most frequently employed anaesthetic technique for lower extremity surgeries. This study is to assess the effect of intrathecal magnesium sulphate with Bupivacaine-Fentanyl spinal anaesthesia for lower extremity surgeries in prolonging the duration of anaesthesia without increasing the incidence of side effects.

\section{MATERIALS AND METHODS}

After getting the approval from the Ethical Committee of the Department of Anaesthesiology, the study was conducted in 70 patients undergoing elective lower extremity surgeries. After getting consent and explaining the procedure details, the anaesthetic technique was performed.

\section{Exclusion Criteria}

- Patient refusal.

- $\quad$ ASA III and IV patients.

- Post spinal surgeries.

- Spinal deformity.

- H/o drug allergy.

After routine preoperative assessment as for all elective surgery patients, they were premedicated with injection Midazolam 2 mg IM 30 - 45 minutes before surgery.

\section{Patients were Randomly Allocated into Two Groups}

Group S - Received Inj. 0.5\% Bupivacaine 2 cc + Inj. Fentanyl $0.5 \mathrm{cc}+0.9 \% \mathrm{NaCl}$ solution $1 \mathrm{cc}$

Group M - Received Inj. 0.5\% Bupivacaine 2 cc + Inj. Fentanyl $0.5 \mathrm{cc}+50 \mathrm{mg}$ of $5 \% \mathrm{MgSO} 41 \mathrm{cc}$

\section{Procedure Details}

On preoperative visit, the patients were explained about the procedure details. Then preoperative baseline parameters like pulse rate, blood pressure, respiratory rate were recorded. IV line started with 18 gauge intravenous cannula and infused with crystalloids.

Patients were put on sitting position and with strict aseptic precaution lumbar puncture was done with Quincke standard 23 gauge spinal needle. The assigned amount of drug is premixed in a sterile syringe. After ensuing free flow of CSF, drug was injected as per the group assigned.

After injection patients were put up in supine position. After attaining adequate peak level of sensory block, the surgeon was asked to proceed. If needed oxygen was given through ventimask.

\section{The Following Parameters were recorded}

1. Time of highest level of sensory block achieved by pin prick.

2. Degree of motor blockade assessed by using Bromage scale.

3. Pulse rate, Blood pressure, respiratory rate, $\mathrm{SpO}_{2}$ were monitored every 2 minutes for 10 minutes and every 5 minutes till the end of surgery.

4. Any discomfort like nausea, vomiting, pruritus and shivering.

5. Hypotension is said to have occurred if there was $30 \%$ fall from baseline and was treated with $100 \% \mathrm{O}_{2}$, intravenous fluid bolus and Inj. Ephedrine in incremental doses.

6. Bradycardia - if present was treated with Inj. Atropine.

7. Sedation score.

8. Incomplete sensory block.

9. Post-operative observation:

a. Duration of procedure.

b. Level at the end of surgery.

c. Duration of post-operative analgesia.

d. Two segment regression time (i.e. the time taken to decrease from maximum sensory level by two segments from initial level is noted).

\section{Sedation Score}

Brain and Ready Sedation Score was Employed

0 - Fully awake.

1 - Drowsy.

2 - Drowsy but arousable on touch (or) call.

3 - Drowsy but arousable on deep stimuli.

4 - Somnolent.

In the post-operative period, total duration of analgesia was taken as that period from time of subarachnoid block till patient requirement of analgesic medicine.

\section{Pain was Evaluated using}

Visual Analog Scale

0 - 1 - Excellent

$2-4$ - Good

$5-6$ - Fair

7 - 8 - Poor

$9-10$ - No relief

Pain score $>6$ - supplementary analgesia given.

\section{Motor Block was Assessed by Bromage Scale}

0 - Full flexion of knees, feet, able to lift the extended leg.

1 - Unable to lift the extended leg. Just able to flex the knees and full flexion of feet possible.

2 - Unable to flex the knees, but flexion of feet possible.

3 - Unable to move the leg (or) feet.

Also in the post-operative period all patients were followed up for any complications like post-operative nausea, vomiting, pruritus, hypotension and respiratory depression. Statistical significance was brought out by ANOVA table.

\section{RESULTS}

In this randomised, single-blinded study conducted in 70 patients, the subjects were allocated into two groups and the following results were observed. 


\section{Demographic Data}

All 2 groups were comparable in age, sex, duration and nature of surgery as shown in Table 1 and 2 and Fig. 1 and 2 .

\section{Highest Dermatomal Level}

The onset of sensory level and time to be taken for the maximum level of achieving the sensory level and sedation score were shown as follows and in Table 7, 8 and 9 and Figure 6, 7 and 8.

\section{Maximum Level Achieved \\ Group S - T6 \\ Group M - T6}

\section{Time of Maximum Sensory Level}

Group S - $6.51 \mathrm{mts}$ with SD 1.04

Group M - 13.06 mts with SD 2.88

\section{Two Segment Regression Time}

Shown in Table 10 as follows:

Group S - 69 mts with SD 6.6

Group M - 75.3 mts with SD 4.9

\section{Onset of Motor Blockade}

Onset and duration of motor blockade were shown in Table 11 and 12 and Fig. 9.

Group S - 10.2 mts with SD 1.5.

Group M - 17.3 mts with SD 2.

\section{Duration of Motor Blockade}

Group S - 97.8 mts with SD 10.1

Group M - 113.1 mts with SD 9.7

\section{Post-Operative Analgesia}

Duration of the procedure and the duration of the postoperative analgesia were shown in Table 13 and 14 and Fig. 10 Group S - 169.4 mts with SD 9.8

Group M - 209 mts with SD 13.4

\section{Haemodynamic Variables}

Percentage of fall in the pulse rate and changes in blood pressure in both groups as follows, shown in the Table 3 and 4 and Figure 3 and 4.

\section{Pulse Rate Changes}

Fall in Pulse Rate

Group S - 13.7 mts with SD 4.8

Group M - 17.5 mts with SD 6.2

\section{Percentage of Change}

Group S - 19.5\% with SD 5.9

Group M - 15.4\% with SD 5.3

\section{Minimum Pulse Rate}

Group S - 71.4/mint with SD 6.3

Group M - 75.4/mint with SD 10.3

\section{Blood Pressure Changes}

With regard to blood pressure, more than 30\% free from the baseline value was considered hypotension. Group S - There was no significant fall in BP Group M - There was no significant fall in BP
Percentage of Fall in Systolic BP

Group S - 14.6\% with SD 4.6

Group M - 21.1\% with SD 3.8

\section{Respiratory Rate and $\mathrm{SPO2}$}

Changes in the respiratory rate and oxygen saturation were shown in Table 5 and 6 and Figure 5 and 6

\section{Respiratory Rate}

Group S - 12.89/min with SD 0.96

Group M - 12.94/min with SD 1.0

\section{SPO2}

Group S - 98.94\% with SD 0.64

Group M - 99.17\% with SD 0.62

\section{Complications}

In the post-operative period, all patients were followed up for any complications and are shown in Table 15 and Fig. 11. The complications occurred in both groups were as follows:

Nausea and Vomiting

Group S - 2.9\%

Group M - NIL

\section{Pruritus}

Group S - 11.4\% (4 Cases)

Group M - 8.6\% (3 Cases)

\begin{tabular}{|c|c|c|c|c|}
\hline \multirow{2}{*}{$\begin{array}{c}\text { Age } \\
\text { Group }\end{array}$} & \multicolumn{2}{|c|}{ Group M } & \multicolumn{2}{c|}{ Group S } \\
\cline { 2 - 5 }$<3$ Years & No. & $\mathbf{\%}$ & No. & \% \\
\hline $30-39$ & 11 & 28.6 & 9 & 25.7 \\
\hline $40-49$ & 7 & 20 & 6 & 17.1 \\
\hline $50-59$ & 6 & 17.1 & 7 & 20 \\
\hline 60 and Above & 1 & 2.9 & 3 & 8.6 \\
\hline Total & $\mathbf{3 5}$ & $\mathbf{1 0 0}$ & $\mathbf{3 5}$ & $\mathbf{1 0 0}$ \\
\hline Range & \multicolumn{2}{|c|}{$20-65$} & \multicolumn{2}{c|}{$22-65$} \\
\hline Mean & \multicolumn{2}{|c|}{37.5} & \multicolumn{2}{c|}{39.7} \\
\hline S. D. & \multicolumn{3}{|c|}{11.5} & \multicolumn{2}{c|}{13} \\
\hline 'p' $\mathrm{p}$ ' Table 1. Age Distribution \\
\hline \multicolumn{5}{|c}{}
\end{tabular}

\begin{tabular}{|c|c|c|c|c|}
\hline \multirow{2}{*}{ Sex } & \multicolumn{2}{|c|}{ Group M } & \multicolumn{2}{c|}{ Group S } \\
\cline { 2 - 5 } & No. & $\mathbf{\%}$ & No. & \% \\
\hline Male & 30 & 85.7 & 30 & 85.7 \\
\hline Female & 5 & 14.3 & 5 & 14.3 \\
\hline Total & $\mathbf{3 5}$ & $\mathbf{1 0 0}$ & $\mathbf{3 5}$ & $\mathbf{1 0 0}$ \\
\hline 'p' ${ }^{\mid}$' & \multicolumn{3}{|c|}{ Not Significant } \\
\hline \multicolumn{4}{|c|}{ Table 2. Sex Distribution } \\
\hline
\end{tabular}

\begin{tabular}{|c|c|c|c|c|c|}
\hline \multirow{2}{*}{ Pulse Rate } & Group M & \multicolumn{2}{c|}{ Group S } & \multirow{2}{*}{$P^{\prime}$} \\
\cline { 2 - 5 } & Mean & S.D. & Mean & S.D. & $\begin{array}{c}\text { 0.842 Not } \\
\text { Significant }\end{array}$ \\
\hline Baseline & 89.2 & 10.5 & 88.9 & 8.3 & $\begin{array}{c}0.5464 \text { Not } \\
\text { Significant }\end{array}$ \\
\hline Change & 0.3 & 3.5 & -1.4 & 4.4 & $\begin{array}{c}0.1 \text { Not } \\
\text { Significant }\end{array}$ \\
\hline \% of change & 0.5 & 3.9 & -1.3 & 4.7 & $\begin{array}{c}0.1085 \text { Not } \\
\text { Significant }\end{array}$ \\
\hline Minimum & 75.4 & 10.3 & 71.4 & 6.3 & $\begin{array}{c}0.1391 \text { Not } \\
\text { Significant }\end{array}$ \\
\hline Change & -13.7 & 4.8 & -17.5 & 6.2 & $\begin{array}{c}0.0068 \text { Not } \\
\text { Significant }\end{array}$ \\
\hline \% of Change & -15.4 & 5.3 & -19.5 & 5.9 & $\begin{array}{c}0.0025 \text { Not } \\
\text { Significant }\end{array}$ \\
\hline Average P.R. & 80.6 & 10.5 & 77.6 & 5.8 & $\begin{array}{c}0.3374 \text { Not } \\
\text { Significant }\end{array}$ \\
\hline \multicolumn{7}{|c|}{ Table 3. Pulse Rate } \\
\hline
\end{tabular}




\begin{tabular}{|c|c|c|c|c|c|}
\hline \multirow{2}{*}{ S. B. P. } & \multicolumn{2}{|c|}{ Group M } & \multicolumn{2}{|c|}{ Group S } & \multirow{2}{*}{ 'P' } \\
\hline & Mean & S.D. & Mean & S.D. & \\
\hline Baseline & 123.3 & 8.4 & 124.0 & 8.8 & $\begin{array}{l}0.5556 \mathrm{Not} \\
\text { Significant }\end{array}$ \\
\hline Maximum & 121.5 & 8.2 & 120.8 & 6.6 & $\begin{array}{l}0.6808 \text { Not } \\
\text { Significant }\end{array}$ \\
\hline Change & -1.8 & 4.2 & -3.3 & 4.2 & $\begin{array}{c}0.0144 \\
\text { Significant }\end{array}$ \\
\hline$\%$ of Change & -1.4 & 3.4 & -2.5 & 3.4 & $\begin{array}{c}0.0139 \\
\text { Significant }\end{array}$ \\
\hline Maximum & 105.4 & 9.4 & 97.7 & 6.5 & $\begin{array}{c}0.0001 \\
\text { Significant }\end{array}$ \\
\hline Change & -17.9 & 5.8 & -26.3 & 5.8 & $\begin{array}{c}0.0001 \\
\text { Significant }\end{array}$ \\
\hline$\%$ of Change & -14.6 & 4.6 & -21.1 & 3.8 & $\begin{array}{c}0.0001 \\
\text { Significant }\end{array}$ \\
\hline Average SBP & 113.6 & 8.3 & 107.7 & 5.9 & $\begin{array}{c}0.0006 \\
\text { Significant }\end{array}$ \\
\hline & $T$ & & I & & \\
\hline
\end{tabular}

\begin{tabular}{|c|c|c|}
\hline 2SR Time & Group M & Group S \\
\hline Mean & 75.3 & 69.0 \\
\hline S.D. & 4.9 & 6.6 \\
\hline 'P' & \multicolumn{2}{|c|}{0.0001 Significant } \\
\hline Table 10. Two Segment Regression Time (Minutes) \\
\hline
\end{tabular}

\begin{tabular}{|c|c|c|}
\hline Motor Onset & Group M & Group S \\
\hline Mean & 17.3 & 10.2 \\
\hline S. D. & 2.0 & 1.5 \\
\hline 'p' & \multicolumn{2}{|c|}{0.0001 Significant } \\
\hline \multicolumn{2}{|c|}{ Table 11. Motor Onset (Minutes) } \\
\hline
\end{tabular}

\begin{tabular}{|c|c|c|}
\hline Motor Duration & Group M & Group S \\
\hline Mean & 113.1 & 97.8 \\
\hline S.D. & 9.7 & 10.1 \\
\hline 'p' & \multicolumn{2}{|c|}{0.0001 Significant } \\
\hline \multicolumn{2}{|c|}{ Table 12. Duration of Motor Block (Minutes) } \\
\hline
\end{tabular}

\begin{tabular}{|c|c|c|c|c|c|}
\hline \multirow{2}{*}{ Parameter } & \multicolumn{2}{|c|}{ Group M } & \multicolumn{2}{c|}{ Group S } & \multirow{2}{*}{ 'P' } \\
\cline { 2 - 5 } & Mean & S.D. & Mean & S.D. & \\
\hline R. R. & 12.94 & 1.0 & 12.89 & 0.96 & $\begin{array}{c}0.9603 \text { Not } \\
\text { Significant }\end{array}$ \\
\hline 'p' & \multicolumn{6}{|c|}{ Tab03 Not Significant } & \\
\hline \multicolumn{6}{|c|}{ Tespiratory Rate/SPO2 } \\
\hline
\end{tabular}

\begin{tabular}{|c|c|c|}
\hline Duration of Procedure & Group M & Group S \\
\hline Mean & 107.4 & 98.8 \\
\hline S.D. & 18.1 & 16.0 \\
\hline 'p' & 0.0762 Significant \\
\hline \multicolumn{2}{|c|}{ Table 13. Duration of Procedure (Minutes) } \\
\hline
\end{tabular}

\begin{tabular}{|c|c|c|c|c|}
\hline \multirow{2}{*}{ SPO2 } & \multicolumn{2}{|c|}{ Group M } & \multicolumn{2}{c|}{ Group S } \\
\cline { 2 - 5 } & Mean & S.D. & Mean & S.D. \\
\hline SPO2 & 99.17 & 0.62 & 98.94 & 0.64 \\
\hline 'P' & \multicolumn{4}{|c|}{0.1331 Not Significant } \\
\hline \multicolumn{4}{|c|}{ Table 6. SPO2 } \\
\hline
\end{tabular}

\begin{tabular}{|c|c|c|}
\hline Duration of Post-Op Analgesia & Group M & Group S \\
\hline Mean & 13.06 & 6.51 \\
\hline S.D. & 2.88 & 1.04 \\
\hline 'p' & 0.0001 Significant \\
\hline Table 14. Duration of Post-Op Analgesia (Minutes) \\
\hline
\end{tabular}

\begin{tabular}{|c|c|c|c|c|}
\hline \multirow{2}{*}{$\begin{array}{c}\text { Onset of } \\
\text { Sensorium }\end{array}$} & \multicolumn{2}{|c|}{ Group M } & \multicolumn{2}{c|}{ Group S } \\
\cline { 2 - 5 } & Mean & S.D. & Mean & S.D. \\
\hline 3 & - & - & 5 & 14.3 \\
\hline 4 & - & - & 6 & 17.1 \\
\hline 5 & 18 & 48.6 & 19 & 54.3 \\
\hline 6 & 9 & 25.7 & 3 & 8.6 \\
\hline 7 & 6 & 17.1 & 1 & 2.9 \\
\hline 8 & 2 & 5.7 & 1 & 2.9 \\
\hline Total & $\mathbf{3 5}$ & $\mathbf{1 0 0}$ & $\mathbf{3 5}$ & $\mathbf{1 0 0}$ \\
\hline Range & $5-8$ & \multicolumn{2}{c|}{$3-8$} \\
\hline Mean & \multicolumn{3}{|c|}{5.77} & \multicolumn{3}{c|}{1.09} \\
\hline S.D. & \multicolumn{3}{|c|}{0.0001 Not Significant } \\
\hline 'P' Table 7. Onset of Sensory Level (In Minutes) \\
\hline \multicolumn{3}{|c|}{} \\
\hline
\end{tabular}

\begin{tabular}{|c|c|c|c|c|c|}
\hline \multirow{2}{*}{ Complication } & \multicolumn{2}{|c|}{ Group M } & \multicolumn{2}{|c|}{ Group S } & \multirow{2}{*}{ 'p' } \\
\cline { 2 - 5 } & No. & $\mathbf{\%}$ & No. & $\mathbf{\%}$ & \\
\hline N.V. & & & & & \\
Yes & - & - & 1 & 2.9 & 0.5 Not \\
No & 35 & 100 & 34 & 97.1 & Significant \\
\hline Pruritus & & & & & \\
Yes & 3 & 8.6 & 4 & 11.4 & 0.5 Not \\
No & 32 & 91.4 & 31 & 88.6 & Significant \\
\hline Any Disturbances & & & & & \\
Yes & - & - & - & - & 1.0 Not \\
No & 35 & 100 & 35 & 100 & Significant \\
\hline \multicolumn{5}{|c}{ Table 15. Complications } \\
\hline
\end{tabular}

\begin{tabular}{|c|c|c|c|c|}
\hline \multirow{2}{*}{ M.S.L. } & \multicolumn{2}{|c|}{ Group M } & \multicolumn{2}{c|}{ Group S } \\
\cline { 2 - 5 } & No. & \% & No. & \% \\
\hline T6 & 27 & 77.1 & 21 & 60 \\
\hline T7 & 4 & 11.4 & 12 & 34.3 \\
\hline T 8 & 4 & 11.4 & 2 & 5.7 \\
\hline Total & $\mathbf{3 5}$ & $\mathbf{1 0 0}$ & $\mathbf{3 5}$ & $\mathbf{1 0 0}$ \\
\hline \multicolumn{3}{|c|}{ Table 8. Maximum Sensory Level } \\
\hline
\end{tabular}

\begin{tabular}{|c|c|c|}
\hline Time of MSL & Group M & Group S \\
\hline Mean & 13.06 & 6.51 \\
\hline S.D. & 2.88 & 1.04 \\
\hline 'p' & \multicolumn{2}{|c|}{0.0001 Significant } \\
\hline Table 9. Time of Maximum Sensory Level \\
\hline
\end{tabular}

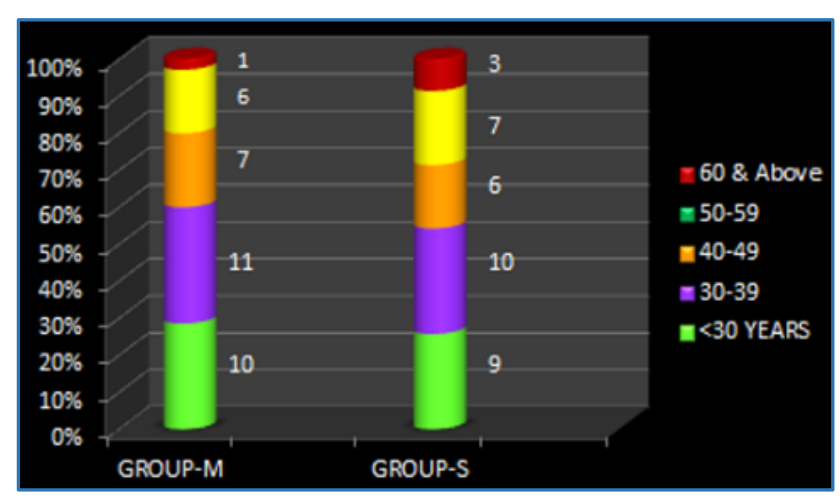

Figure 1. Age Distribution 


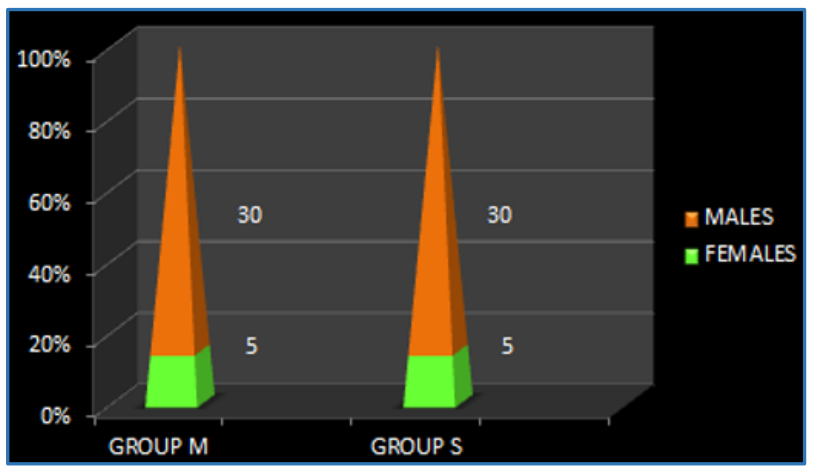

Figure 2. Sex Distribution

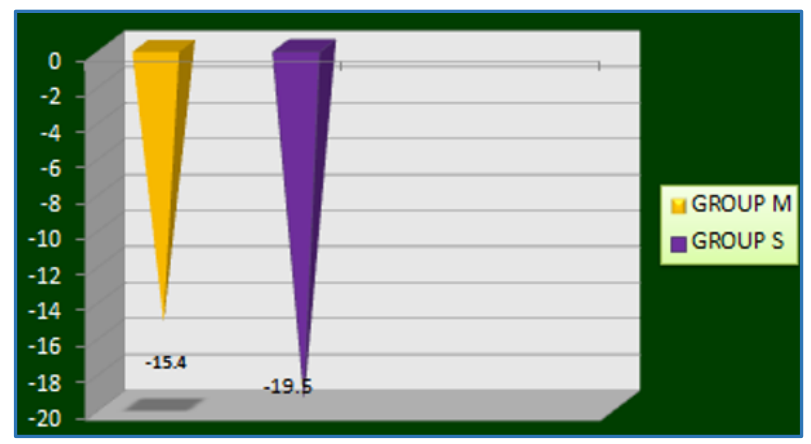

Figure 3. Percentage of Changes in Pulse Rate

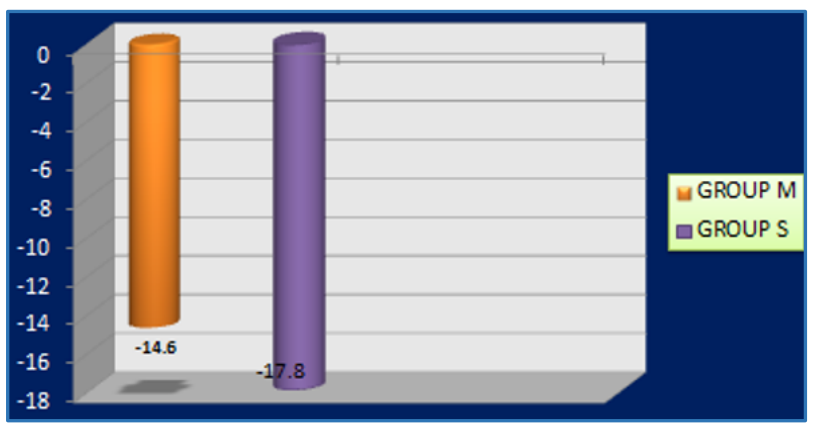

Figure 4: Percentage of Changes in Blood Pressure

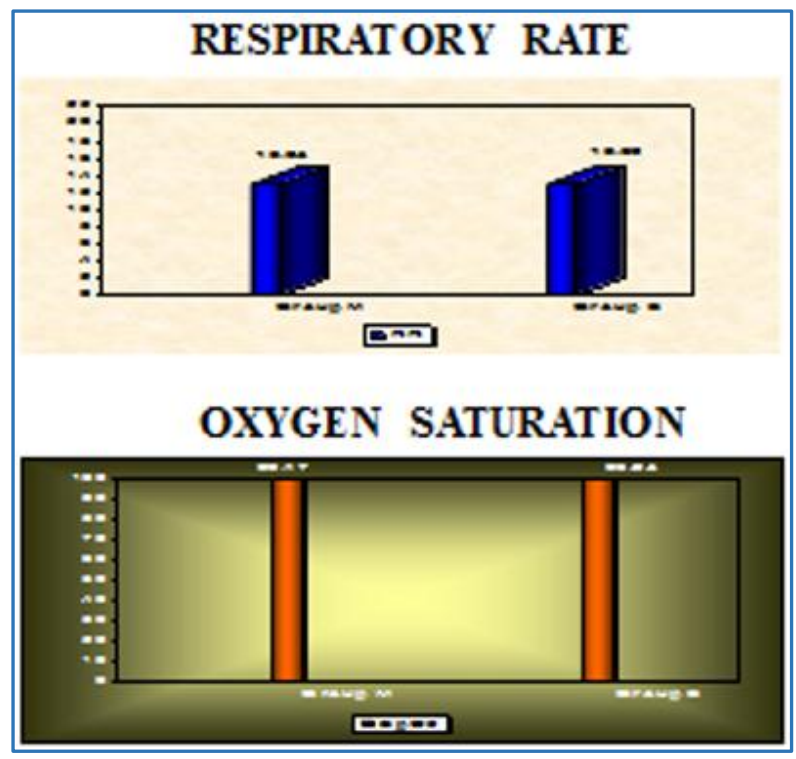

Figure 5. Respiratory Rate and Oxygen Saturation

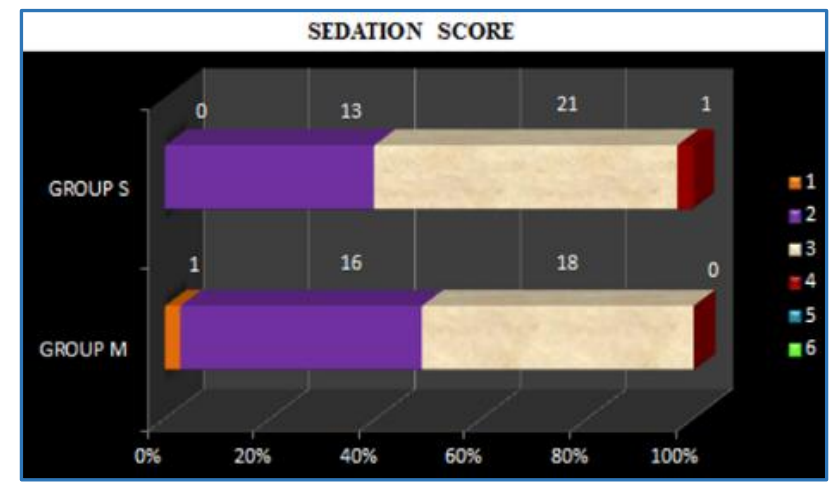

Figure 6. Sedation Score

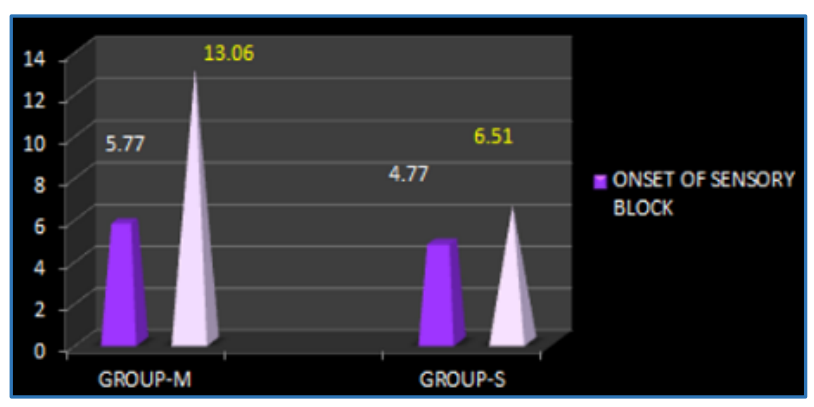

Figure 7. Onset of Sensory Block and Time of Maximum Sensory Level (In Minutes)

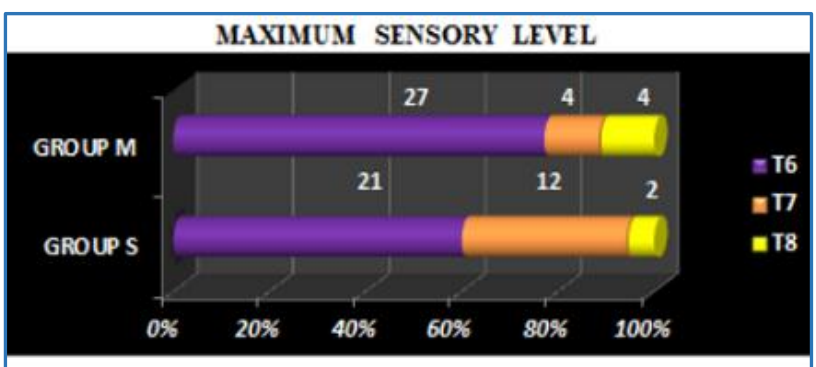

TWO SEGMENT REGRESSION TIME

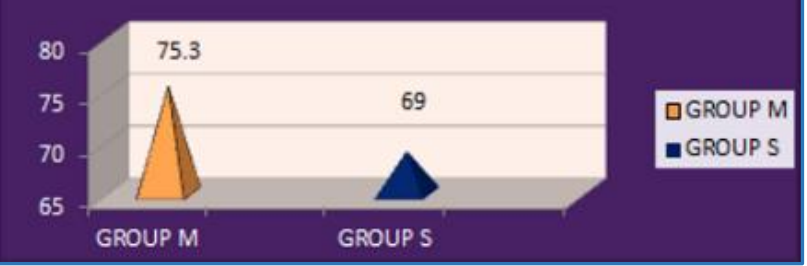

Figure 8. Maximum Sensory Level

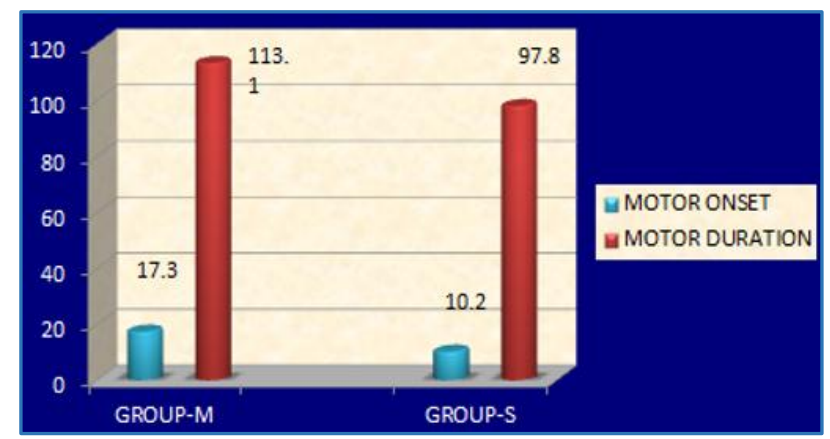

Figure 9. Onset and Duration of Motor Blockade 


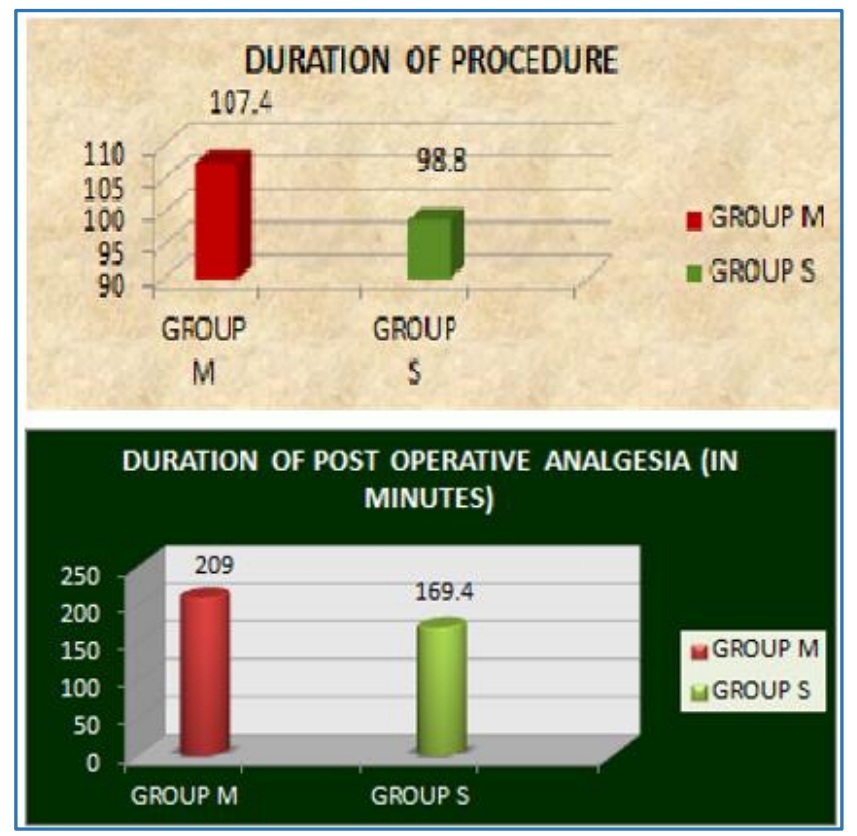

Figure 10. Duration of Procedure and Duration of Post-Operative Analgesia (In Minutes)

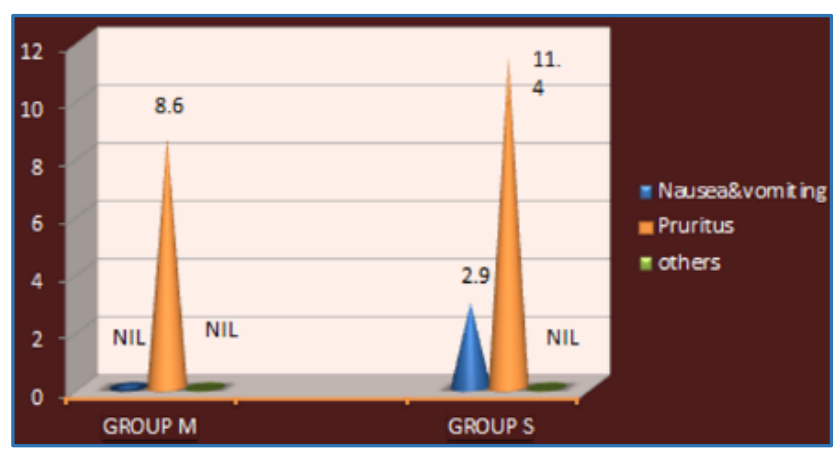

Figure 11. Complications

\section{DISCUSSION}

The pain we perceive after a burn, bite (or) pinch is readily identifiable but difficult to define, because it is differently perceived at different threshold.

Pain is defined as psychical adjunct of protective reflex by Sherington in 1906.

The International Association of Society for Pain (IASP) defined it as "An unpleasant sensory and emotional experience associated with actual (or) potential tissue damage (or) described in terms of such damage."

The use of opioids to control pain exists even in ancient history and opioids are still the primary analgesic chosen for severe pain. But adding magnesium sulphate to BupivacaineFentanyl spinal anaesthesia prolong the post-operative analgesia in a different mechanism, mainly by NMDA blockade.

\section{Advantages of Intrathecal Magnesium in this Study}

The main finding of this study is that in patients undergoing lower extremity surgery under bupivacaine-fentanyl spinal anaesthesia, the addition of $50 \mathrm{mg}$ IT MgSO4 led to a significant delay in the onset of both sensory and motor blockade and prolonged the duration of spinal anaesthesia without increasing side effects. ${ }^{9,10,11,12}$

The delay in onset observed in this study with IT magnesium during IT bupivacaine and fentanyl has not been reported previously except Ozalevli et al. It is possible that the solution to which $\mathrm{MgSO} 4$ was added had a different $\mathrm{pH}$, which might explain our findings. However, we cannot offer a satisfactory explanation for this delay and further studies are needed.

\section{Duration of Post-0p Analgesia}

The mean duration of spinal anaesthesia was significantly prolonged by magnesium $13,14,15,16,17$ to 209 mins., compared with 169.4 mins. in Group S, which is consistent with the findings of Buvanendran et al( ${ }^{(4)}$ and Ozalevli et al.

\section{Two-Segment Regression Time}

Two-segment regression time was significantly prolonged in Group M “P” 0.0001.

\section{Haemodynamics}

The haemodynamics were stable in Magnesium group than Group S (P - 0.0001). This observation is similar to et al.

\section{Sedation}

There is no significant difference between two groups.

\section{Pruritus}

The incidence of pruritus in Group M is 8.6\% and in Group S is $11.4 \%$. Nausea and vomiting was found in one case in Group S.

\section{Respiratory Depression}

The use of IT opioids is associated with the risk of respiratory depression. 18,19,20 However, fentanyl, a lipid-soluble opioid binds fairly rapidly with the opioid receptors in the dorsal horn of the spinal cord leaving only small amounts of substance for cephalad migration to the fourth ventricle in contrast with the less lipid-soluble morphine. Varassi et al(19) reported that the subarachnoid administration of $25 \mathrm{mg}$ of fentanyl during spinal anaesthesia in non-premedicated men did not cause early respiratory depression in elderly patients. An increased risk of respiratory depression in labouring. No case had respiratory depression intraoperatively as well as in post-operative period in this study. In this study, the respiratory rate remained unchanged with the baseline.

The safety of IT magnesium administration has been evaluated in animal and human studies. In rats, boluses of magnesium produced transient motor and sensory block with no adverse clinical or histological consequences. In a randomised, controlled canine study, no neurological deficit or change in cord histopathology was reported following IT magnesium administration ( 45 - $60 \mathrm{mg}$ ). A recent human study found no deleterious effects of IT magnesium on spinal opioid analgesia in labouring parturients. Thus, IT MgSO4 seems to have a good safety profile.21,22,23,24,25

The dose of magnesium used in this study was based on data from Buvanendran et al and Ozalevli et al, where $50 \mathrm{mg}$ of IT MgSO4 potentiated fentanyl antinociception. Larger doses have also been used. In 1985, Lejuste(17) described the inadvertent IT injection of $1000 \mathrm{mg}$ of $\mathrm{MgSO} 4$ producing a dense motor block followed by complete resolution within 90 mins. with no neurological deficit at long-term followup. Further investigation is required to determine whether larger doses of magnesium produce greater potentiation of spinal analgesia without causing any neurological deficit when administered intrathecally. 


\section{CONCLUSION}

This study is conducted in patients aged 20 - 65 years. Magnesium sulphate is added intrathecally in the dose of 50 mg to Bupivacaine Fentanyl spinal anaesthesia for lower extremity surgeries.

Magnesium sulphate delayed the onset of both sensory and motor blockade and prolonged the duration of anaesthesia; in Group $\mathrm{M}$ the haemodynamics were stable with significant prolongation of post-operative analgesia than other group.

In Group F $11.8 \%$ of the patients had intraoperative discomfort who needed supplemental intravenous analgesia.

From this study, it was concluded that in patients undergoing lower extremity surgery, IT MgSO 4 (50 mg), when added to spinal anaesthesia induced by bupivacaine and fentanyl, delayed the onset of both sensory and motor blockade and prolonged the duration of anaesthesia without increasing the incidence of side effects.

\section{REFERENCES}

1. Begon S, Pickering G, Eschalier A, et al. Magnesium increases morphine analgesic effect in different experimental models of pain. Anesthesiology 2002;96(3):627-32.

2. Buvanendran A, McCarthy RJ, Kroin JS, et al. Intrathecal magnesium prolongs fentanyl analgesia: a prospective, randomized, controlled trial. Anesth Analg 2002;95(3):661-6.

3. Brockway MS, Noble DW, Sharwood-Smith GH, et al. Profound respiratory depression after extradural fentanyl. Br J Anaesth 1990;64(2):243-5.

4. Ozalevli M, Cetin TO, Unlugenc $\mathrm{H}$, et al. The effect of adding intrathecal magnesium sulphate to bupivacaine-fentanyl spinal anaesthesia. Acta Anaesthesiol Scand 2005;49(10):1514-9.

5. Ascher P, Nowak L. Electrophysiological studies of NMDA receptors. Trends Neurosci 1987;10(7):284-8.

6. Kroin JS, McCarthy RJ, Von Roenn N, et al. Magnesium sulfate potentiates morphine antinociception at the spinal level. Anesth Analg 2000;90(4):913-7.

7. Tramer MR, Schneider J, Marti RA, et al. Role of magnesium sulfate in postoperative analgesia. Anesthesiology 1996;84(2):340-7.

8. Simpson JI, Eide TR, Schiff GA, et al. Intrathecal magnesium sulfate protects the spinal cord from ischemic injury during thoracic aortic cross clamping. Anesthesiology 1994;81(6):1493-9.

9. Dickenson AH. NMDA receptor antagonists: interaction with opioids. Acta Anaesthesiol Scand 1997;41(1 Pt 2):112-5.

10. Togal T, Demirbilek S, Koroglu A, et al. Effects of $S(b)$ ketamine added to bupivacaine for spinal anaesthesia for prostate surgery in elderly patients. Eur J Anaesthesiol 2004;21(3):193-7.
11. Hooda S, Malhotra N, Kumar L. Evaluation of three doses of intra thecal bupivacaine with fentanyl in geriatric patients undergoing hip surgery. J of Anaesthesia Clinical Pharmacology 2006;22(3):267-72.

12. Wilder-Smith $\mathrm{OH}$, Arendt-Nielsen L, Gäumann D, et al. Sensory changes and pain after abdominal hysterectomy: a comparison of anesthetic supplementation with fentanyl versus magnesium or ketamine. Anesth Analg 1998;86(1):95-101.

13. Mao J, Price DD, Mayer DJ. Mechanisms of hyperalgesia and morphine tolerance: a current view of their possible interactions. Pain 1995;62(3):259-74.

14. Xiao WH, Bennett GJ. Magnesium suppresses neuropathic pain responses in rats via a spinal site of action. Brain Res 1994;666(2):168-72.

15. Yamamoto T, Yaksh TL. Studies on the spinal interaction of morphine and the NMDA antagonist MK-801 on the hyperesthesia observed in a rat model of sciatic mononeuropathy. Neurosci Lett 1992;135(1):67-70.

16. Ko SH, Lim HR, Kim DC, et al. Magnesium sulfate does not reduce postoperative analgesic requirements. Anesthesiology 2001;95(3):640-6.

17. Lejuste MJ. Inadvertent intrathecal administration of magnesium sulfate. S Afr Med J 1985;68(6):367-8.

18. Etches R, Sandler A, Daley M. Respiratory depression and spinal opioids. Can J Anaesth 1989;36(2):165-85.

19. Varassi G, Celleno D, Capogna G, et al. Ventilatory effects of subarachnoid fentanyl in the elderly. Anesthesia 1992;47(7):558-62.

20. Witlin AG, Sibai BM. Magnesium sulfate therapy in preeclampsia and eclampsia. Obstet Gynecol 1998;92(5):883-9.

21. Arcioni R, Palmisani S, Tigano $S$, et al. Combined intrathecal and epidural magnesium sulphate supplementation of spinal anesthesia to reduce postoperative analgesic requirements: a prospective, randomized, double blind, controlled trial in patients undergoing major orthopedic surgery. Acta Anaesthesiol Scand 2007;51(4):482-9.

22. Bilir A, Gulec S, Erkan A, et al. Epidural magnesium reduces post-operative analgesic requirements. $\mathrm{Br} \mathrm{J}$ Anaesth 2007;98(4):519-23.

23. Sirvinskas E, Laurinaitis R. Use of magnesium sulphate in anesthesiology. Medicina 2002;38(7):695-8.

24. Mizutani A, Taniguchi K, Miyagawa A, et al. The analgesic effect of iontophoresis with magnesium sulphate. Masui 1995;44(8):1076-9.

25. James MF. Clinical use of magnesium infusions in anesthesia. Anesth Analg 1992;74(1):129-36. 